\title{
Kożuchów - historyczne miasto z przyszłością
}

\section{Wojciech Eckert}

\author{
Instytut Budownictwa, Wydział Budownictwa, Architektury i Inżynierii Środowiska \\ Uniwersytet Zielonogórski, e-mail: w.eckert@ib.uz.zgora.pl
}

\begin{abstract}
Streszczenie: Kożuchów jest miastem wyjątkowym, nie tylko w skali województwa lubuskiego ale w skali kraju. Zachowany w bardzo dobrym stanie system obronny, składający się z dwóch pierścieni kurtyn oraz fosy, wyróżnia je spośród setek innych. Należy jednocześnie do najstarszych miast Środkowego Nadodrza. Zachowane prawie na całym obwodzie fortyfikacje uniemożliwiły scalenie się centrum z przedmieściami. Dzięki temu zachowało się pierwotne rozplanowanie tej części miasta i jego historyczny charakter. Te walory są jednak dużym wyzwaniem dla urbanistów i architektów w pracach planistyczno-urbanistycznych. Samo stare miasto stało się miejscem węzłowym w układzie przestrzennym Kożuchowa. Ponadto, w nim samym, jest wiele dodatkowych węzłowych miejsc. Są to budowle mające znaczące wartości kulturowe: zamek, ratusz, gotycki kościół, zabudowa mieszkalna. Jest to również system fortyfikacyjny z dobrze zachowanymi kurtynami, basztami, bastejami i fosą. Historyczny układ ulic nie ułatwia komunikacji pieszej i samochodowej na Starówce. Tereny zielone kryją ogromny potencjał. Niestety jest też dużo elementów degradujących miasto: budynki gospodarcze, zaniedbane podwórka, współczesna zabudowa tzw. bloki, pawilony handlowe, niezabudowane działki i kwartały. W opracowaniu przedstawiono próbę analizy problemów oraz propozycje zmian aby zachowany został wyjątkowy charakter tego miasta a jednocześnie powstała wartość dodana wynikająca z wprowadzenia propozycji nowych rozwiązań architektonicznych i urbanistycznych.
\end{abstract}

Słowa kluczowe: urbanistyka, architektura, układ przestrzenny, stare miasto, system obronny, rewitalizacja.

\section{Wprowadzenie - zarys dziejów miasta}

Kożuchów należy do najstarszych miast Środkowego Nadodrza. We wczesnym średniowieczu prawdopodobnie istniał tu gród, który wchodził w skład państwa plemiennego Dziadoszan. W pobliżu grodu krzyżowały się ważne szlaki handlowe wiodące z Wrocławia do Krosna Odrzańskiego. Korzystne położenie grodu sprawiło, że w jego pobliżu rozwinęła się osada targowa, która już w 1125 roku posiadała swój kościół. Na początku XIII stulecia Kożuchów był już znacznym ośrodkiem miejskim, złożonym z rozproszonych członów osadniczych: grodu, osady targowej, rzemieślniczego podgrodzia z kościołem, komory celnej, karczmy i młyna.

W pierwszej połowie XIII wieku doszło do wytyczenia miasta o regularnym rozplanowaniu. Miasto lokacyjne zajmowało niewielki obszar, całe założenie stanowił prostokątny rynek i otaczające go kamienice z działkami oraz plac, na którym znajdował się jednonawowy kościół i cmentarz. Budynki mieszkalne były płytkie, powiększenie nastąpiło później wraz z powstaniem uliczek (dzisiejsza ul. Kościelna, Klasztorna, Legnicka, Daszyńskiego, Limanowskiego, Obywatelska, 1 Maja) wychodzących pod kątem prostym z narożników 
rynku. Wznoszono wówczas domy drewniane, parterowe, z otwartymi przejazdami na zaplecza posesji, gdzie znajdowały się ogrody warzywne i zabudowa gospodarcza. W pobliżu miasta, w odległości około 70 m na północ, znajdował się zamek i młyn wodny. W połowie XIII wieku, w miejscu dawnej świątyni, wzniesiono kościół murowany trójnawowy z długim prostokątnym prezbiterium. Wkrótce, za zgodą księcia głogowskiego Konrada, teren Kożuchowa został powiększony do wielkości objętej później obwarowaniami. Powstały nowe ulice (dzisiejsza ul. Mickiewicza, Głogowska, Krzywoustego), a dotychczasowe zostały przedłużone.

Przypuszcza się, że analogicznie do Głogowa, miasto zostało otoczone wałem i palisadą. Pod koniec XIII wieku w większości miast śląskich, a wśród nich i w Kożuchowie, wały z palisadami zastąpiono murami z kamienia polnego układanego warstwowo. Mury w Kożuchowie miały wysokość ponad $8 \mathrm{~m}$ i grubość od 1,5 do 1,9 m. Od strony wewnętrznej w górnej partii zwężały się uskokowo tworząc osłonięty od zewnątrz ganek o szerokości ok. $1 \mathrm{~m}$. Ganek umożliwiał komunikację między basztami, rozmieszczonymi na całym obwodzie murów co 48 - $58 \mathrm{~m}$. Baszty były wyższe, wysunięte przed lico murów, otwarte od wewnątrz, zwieńczone drewnianymi hurdycjami. Mury otoczono fosą o szerokości do $22 \mathrm{~m}$ i wałem ziemnym o wysokości 6 m. Trzy bramy Głogowska, Krośnieńska i Żagańska były budowlami piętrowymi z przejazdem w parterze i pomieszczeniem dla strażników na piętrze. W XV wieku system obronny został wzmocniony drugim pasem murów, rozciągających się od zachodniego skrzydła zamku do bramy Głogowskiej, wyposażonych w półkoliste basteje.

Na przełomie XV i XVI wieku księstwo głogowskie i Kożuchów przeżywały swój rozkwit. Książę Zygmunt Jagiellończyk usadowił na zamku w Kożuchowie silny oddział, którego zadaniem było zwalczanie rozbójnictwa. W 1516 roku kożuchowski zamek wszedł w posiadanie Jana von Rechenberga. Za jego rządów wprowadzono w mieście luteranizm.

W XIV-XV wieku utrwalił się model wąskiej działki, budynki były sytuowane szczytowo do ulicy. Po pożarze w 1554 roku cała zabudowa wokół rynku została wzniesiona z kamienia i cegły, piwnice i mury dwóch kondygnacji nadziemnych zachowały się do dzisiaj. Po następnym pożarze w 1764 roku władze miejskie nakazały stosować przy odbudowie trzy kondygnacje dla kamienic rynkowych i dwie dla zabudowy poza strefą rynku.

Wydarzenia wojny trzydziestoletniej były dotkliwe dla miasta, z obecnością wojska wiązały się pożary, gwałty, grabieże, prześladowania religijne. Po wojnie Kożuchów stracił wiele swoich praw i przywilejów. Powoli jednak miasto podnosiło się z upadku, odbudowano i przebudowano wiele obiektów, między innymi kościół farny i ratusz. Rozbudowały się przedmieścia, na jednym z nich ewangelicy zbudowali swój cmentarz (dzisiejsze lapidarium). W czasie wojny północnej do Kożuchowa wkroczyły wojska szwedzkie Karola XII. W 1709 roku za murami miasta wzniesiono kościół ewangelicki, a kilka lat później szkołę.

W XVII wieku miasto nawiedziły liczne epidemie, klęski nieurodzaju, pożary. Efektem toczących się od XVII do XIX wieku wojen był upadek gospodarczy miasta. Pierwsza fabryka włókiennicza pojawiła się w mieście już w końcu XVIII wieku, jednak rozwój przemysłu w Kożuchowie był bardzo powolny. Główną przyczyną był brak wody w mieście. Ponadto doświadczeni wojnami mieszkańcy nie zgodzili się, by przez Kożuchów przebiegała szosa Berlin-Wrocław. Droga, którą rozpoczęto w 1817 roku, przecięła Nową Sól, a Kożuchów został na uboczu ważnych szlaków komunikacyjnych.

W 1849 roku rozbudowano ratusz, a w 1869 roku uruchomiono nowy szpital, w 1909 r. wprowadzono elektryczne oświetlenie i uruchomiono wodociągi miejskie, likwidując lampy naftowe oraz drewniane rury i zbiorniki na wodę. Na przełomie XIX i XX wieku rozbudowały się przedmieścia, szczególnie tereny położone po wschodniej stronie miasta. 
Tam też wzniesiono w roku 1890 dworzec kolejowy. Kożuchów otrzymał połączenie kolejowe z Nową Solą i Żaganiem. W zachodniej części miasta, w latach trzydziestych XX wieku, powstały obszerne koszary wojskowe. Działania wojenne II wojny światowej ominęły Kożuchów. Pod koniec 1943 roku zorganizowano w mieście filię obozu koncentracyjnego Gross-Rosen. Więźniowie byli zatrudnieni w miejscowych zakładach przemysłowych, rolnictwie i w warsztatach rzemieślniczych. 14 lutego 1945 roku miasto zajęły wojska radzieckie, a latem tego roku zorganizowano polską administrację. Po wojnie Kożuchów nadal był siedzibą władz powiatowych, w 1953 roku zlikwidowano powiat kożuchowski, a władze powiatowe przeniesione zostały do Nowej Soli.

\section{Plany rewitalizacji Kożuchowa. Próba określenia miejsc węzłowych starego miasta}

W ostatnich latach, na Wydziale Budownictwa, Architektury i Inżynierii Środowiska Uniwersytetu Zielonogórskiego, prowadzono prace, których celem było znalezienie cech charakterystycznych, jakie posiadają wybrane miasta średniej wielkości w województwie lubuskim, które mogłyby być wykorzystane w planach ich rewitalizacji. Np. Krosno Odrzańskie, którego stare miasto zostało zniszczone prawie w całości wskutek działań II wojny światowej i do dzisiaj nie jest odbudowane. Ośno Lubuskie, częściowo zniszczone lecz zamknięte, $\mathrm{z}$ doskonale zachowanym, pierścieniem średniowiecznych fortyfikacji. Gubin, z centrum zniszczonym w czasie wojny, później częściowo, chaotycznie zabudowanym, z potężną, gotycką sylwetką kościoła farnego. Jednym z nich jest Kożuchów, historyczne miasto zamknięte średniowiecznymi fortyfikacjami, które przez dziesięciolecia ulegało powolnej degradacji.

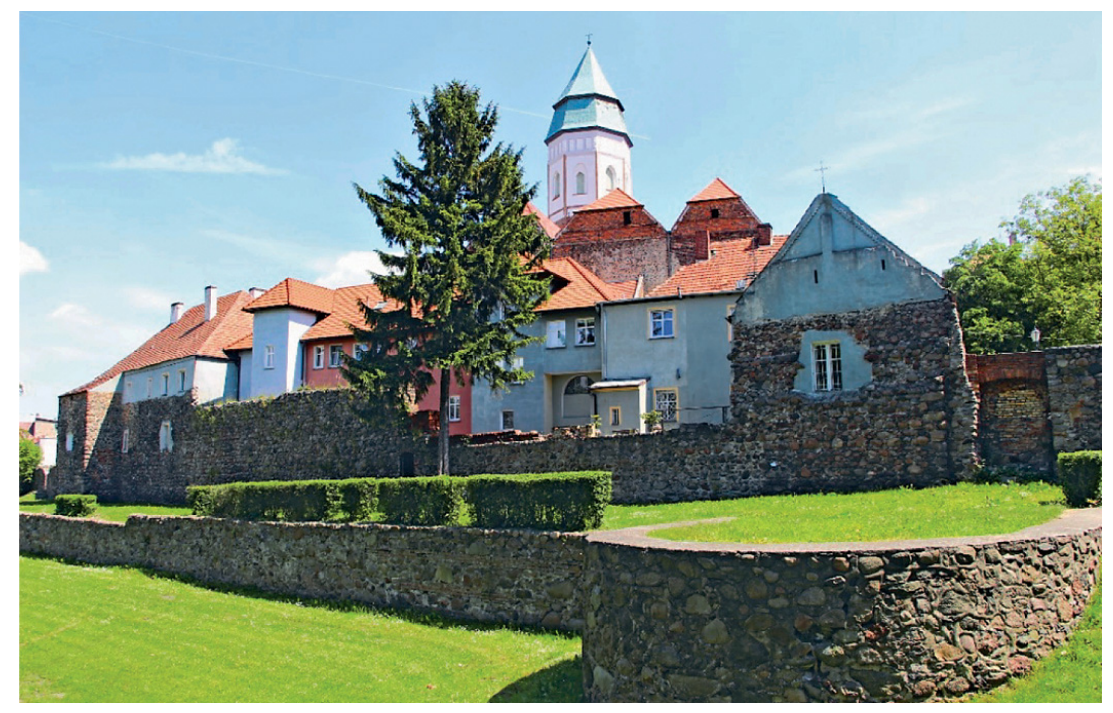

Fot. 1. Kożuchów, widok starego miasta od strony zachodniej

Opracowane zostały założenia do planu rewitalizacji starego miasta bazujące na elementach identyfikujących to miasto, będących zarówno miejscami węzłowymi, które powinny być wykorzystane w planach rewitalizacji. Są to przede wszystkim: 
Zamek, wzniesiony w pierwszej połowie XIV wieku na miejscu średniowiecznego grodu kasztelańskiego. Przez lata był siedzibą książęcą, rezydencją możnych rodów, klasztorem zakonu karmelitów, zbrojownią. Zbudowany w stylu gotyckim, obecnie o zatartych znamionach stylowych. Obiekt powiązany jest z systemem obronnym miasta.

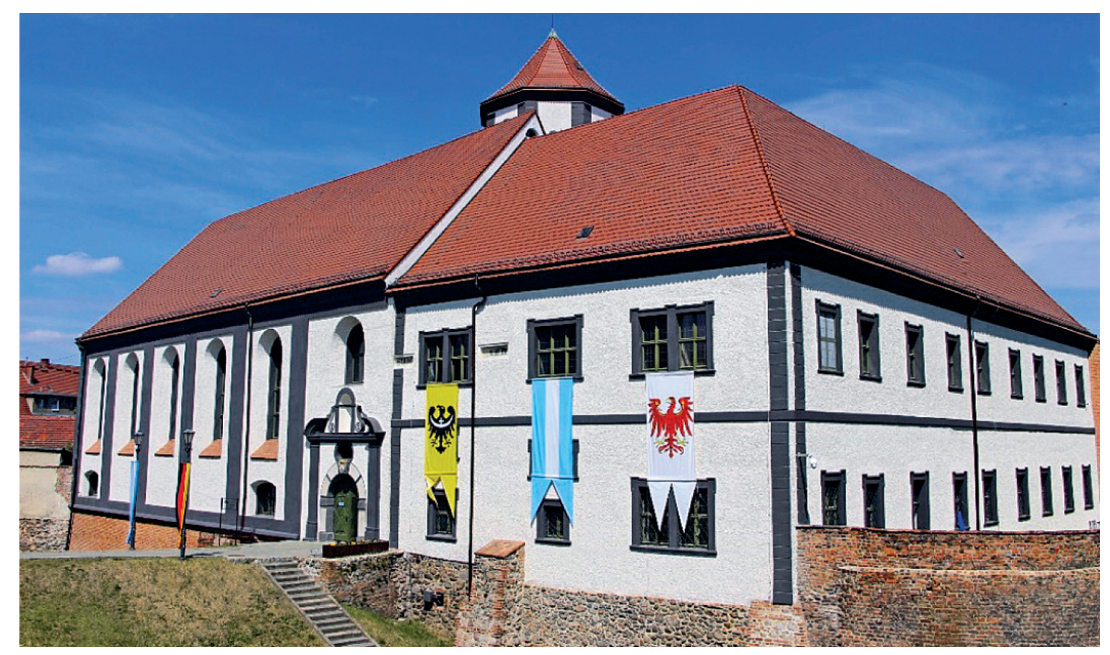

Fot. 2. Kożuchów, zamek, widok od południowego wschodu

Mury obronne, zbudowane na przełomie XIII i XIV wieku w miejscu wcześniejszych umocnień drewniano-ziemnych. Wykonane z kamienia polnego, układanego warstwowo. Pierścień murów opasywała dochodząca miejscami do 20 metrów szerokości fosa. Do miasta można było dotrzeć trzema bramami: Głogowską, Krośnieńską i Żagańską. Później w południowej części przebito czwartą bramę zwaną Szprotawską. W 1764 roku, po wielkim pożarze, cześć fortyfikacji została rozebrana - materiał wykorzystano do budowy domów. Mury i fosa do dziś zachowały się niemal w pierwotnej długości i są unikatem w skali kraju.

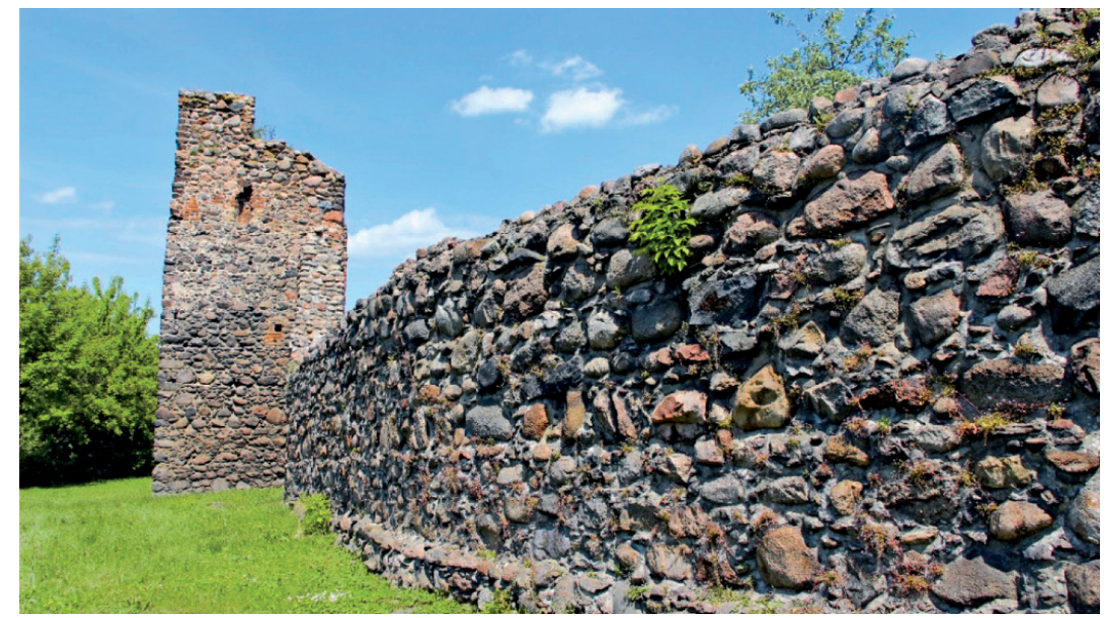

Fot. 3. Kożuchów, fragment murów obronnych, widok od zachodu 


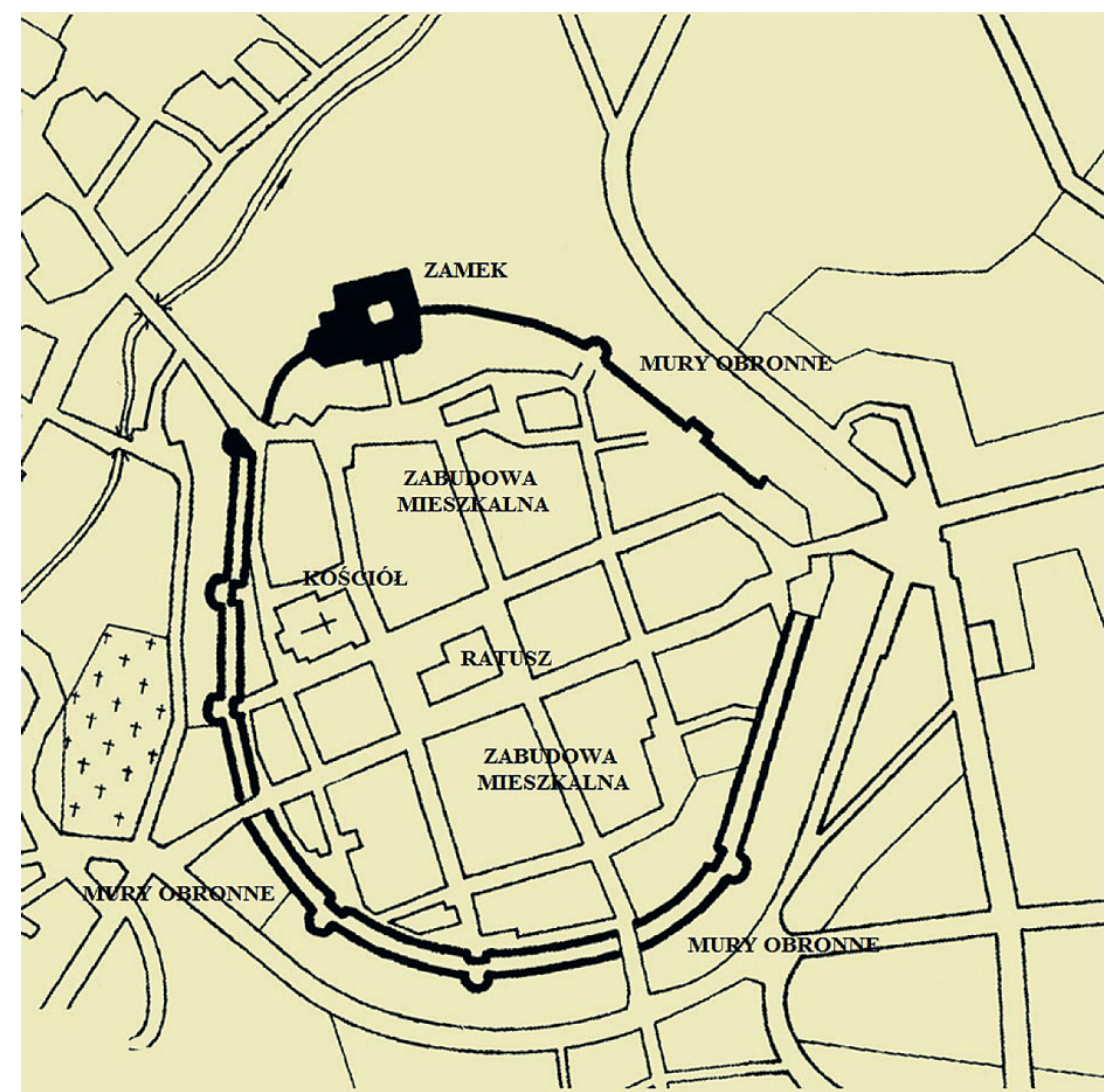

Rys. 1. Średniowieczne fortyfikacje miasta. (wg. St. Kowalski, J. Muszyński)

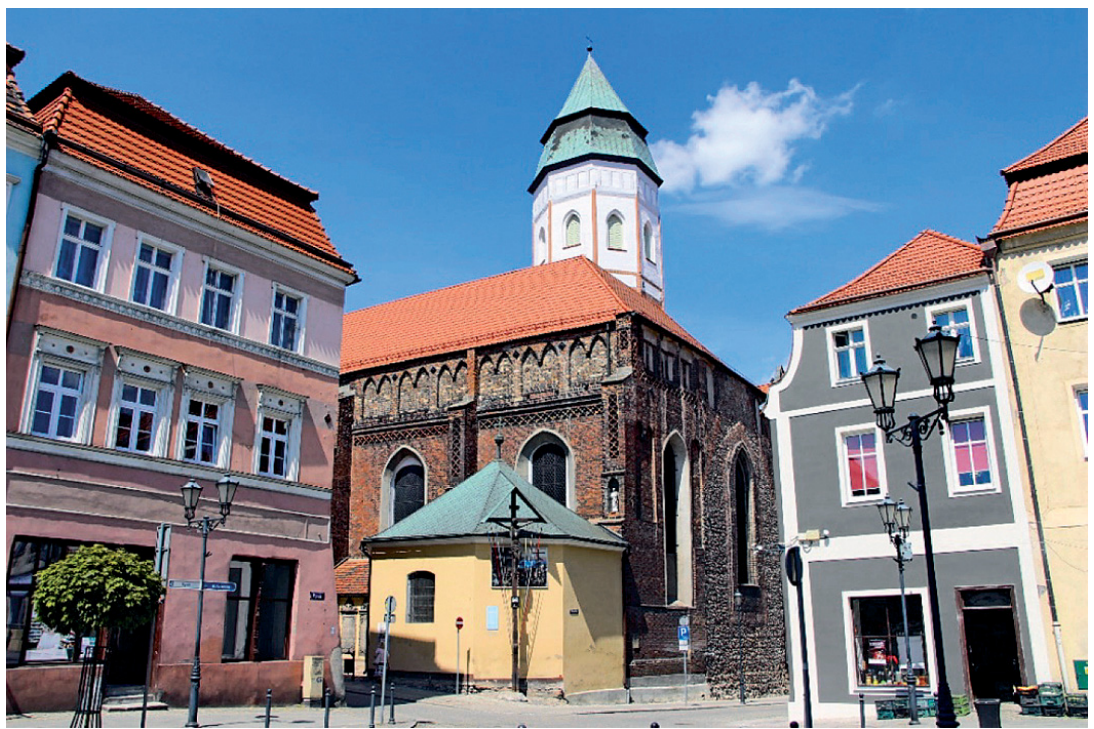

Fot. 4. Kożuchów, kościół parafialny pw. Oczyszczenia NMP 
Kościól, zbudowany w XIII wieku jako jednonawowa, kamienna budowla. Wielokrotne przebudowy spowodowały że dzisiaj kościół jest trzynawową budowlą z kamienia i cegły. Główna bryła kościoła utrzymana jest w stylu gotyckim, wieża i dach prezentują styl barokowy, sklepienia naw i prezbiterium renesansowy. Na elewacjach wmurowanych jest kilkanaście renesansowych, płaskorzeźb nagrobnych.

Ratusz, wzniesiony na początku XIV wieku jako murowany, piętrowy budynek, usytuowany w północnej części placu rynkowego. Obiekt spłonął w 1488 roku, zachowały się tylko przesklepione piwnice ukryte pod nawierzchnią rynku dostępne z podziemi obecnego ratusza. W roku 1489 wzniesiono następny ratusz późnogotycki. Ratusz był budowlą piętrową murowaną z cegły nakrytą dachem dwuspadowym, z dekorowanymi szczytami w postaci ostrołukowych wnęk i sterczyn. Otwory posiadały profilowane obramienia ceramiczne. Wieża ratuszowa $\mathrm{z}$ dzwonem i zegarem nie była związana z bryłą ratusza. Liczne pożary sprawiały wiele zniszczeń i liczne przebudowania. W XIX wieku ratusz został rozbudowany o neoklasycystyczny fragment budowli. Spalony w 1945 roku, po wojnie został przebudowany, łącząc elementy historyczne ze współczesnymi.

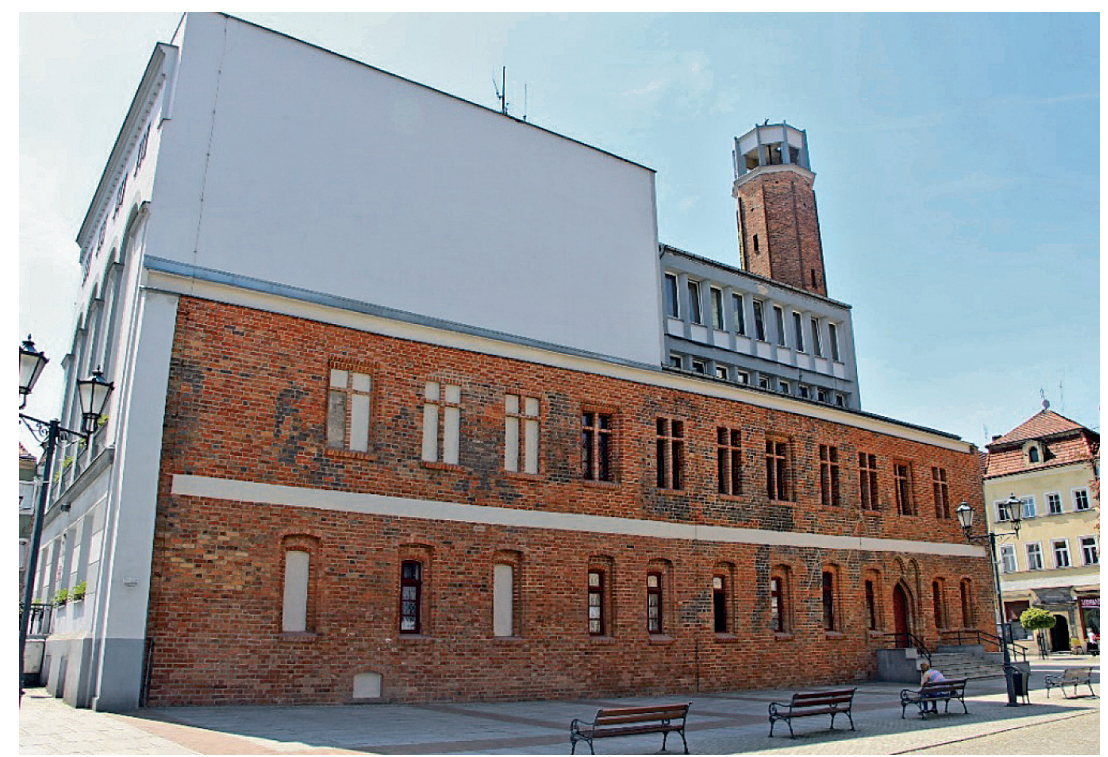

Fot. 5. Kożuchów, późnogotycki ratusz z powojenną rozbudową

Zabudowa mieszkalna, zespół zabytkowych domów liczy ponad 270 obiektów. Zachowane kamienice pochodzą z okresów od XVI do początku XX wieku. Kamienice na Rynku są usytuowane na parcelach ze średniowiecznym rodowodem. Na niektórych elewacjach zachowały się portale z okresu renesansu. Przy ul. Klasztornej 6 zachowała się bogato zdobiona, przedstawiająca płaskorzeźby św. Piotra i Pawła, fasada pochodząca z XVIII wieku. 


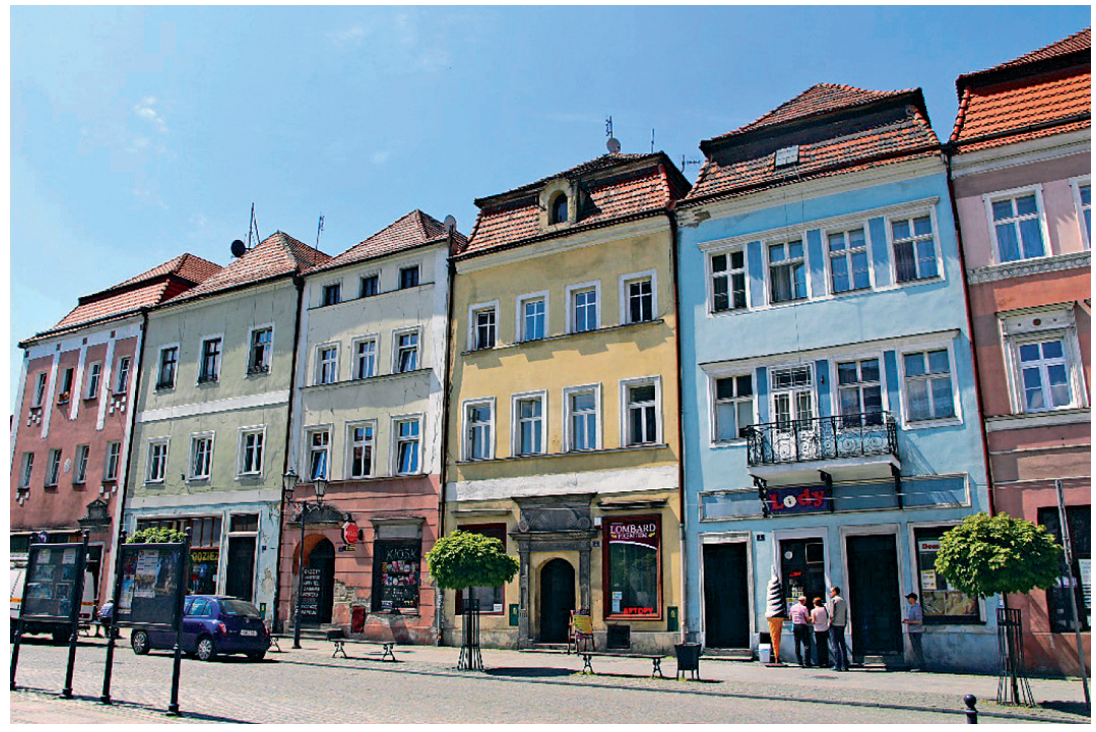

Fot. 6. Kożuchów, kamienice w zachodniej pierzei starego rynku

\section{Elementy degradujące miasto}

Przestrzeń urbanistyczna Starego Miasta w Kożuchowie w przeciągu ostatnich kilkudziesięciu lat uległa znacznej degradacji. Na przestrzeń tą składają się trzy podstawowe elementy:

- tereny o nieokreślonej funkcji miejskiej,

- tereny o niewłaściwym sposobie wykorzystania,

- tereny niewykorzystane.

Strefy te zlokalizowane są przede wszystkim we wschodniej i południowej części miasta. W programie rewitalizacji Kożuchowa określono tereny, które należy odzyskać dla funkcji miejskich i centrotwórczych oraz tereny, które należy przeznaczyć pod nową zabudowę. W tym celu postuluje się opracowanie programów funkcjonalno - przestrzennych dla wszystkich kwartałów Starego Miasta. Również zabudowa kubaturowa Kożuchowa podlegała silnym, niekorzystnym przeobrażeniom. Licznie reprezentowane są obiekty powodujące dysonans przestrzenny. Są to przede wszystkim budynki wzniesione po II wojnie światowej. Pawilony handlowe, bloki mieszkalne, budynki użyteczności publicznej a nawet domy jednorodzinne.

W programie rewitalizacji staromiejskiego centrum Kożuchowa wskazano te tereny oraz budynki. Sposób ich zagospodarowania lub modernizacji pozostawia się inicjatywie projektantów. Należy jednak dążyć do przywrócenia historycznego układu urbanistycznego w skali poszczególnych kwartałów a w skali poszczególnych budynków do przywrócenia klimatu typowego dla zwartej zabudowy centrum miasta.

\section{System komunikacyjny}

System komunikacyjny Starego Miasta w Kożuchowie dzieli się na dwie strefy:

- ruchu kołowego,

- ruchu pieszego. 


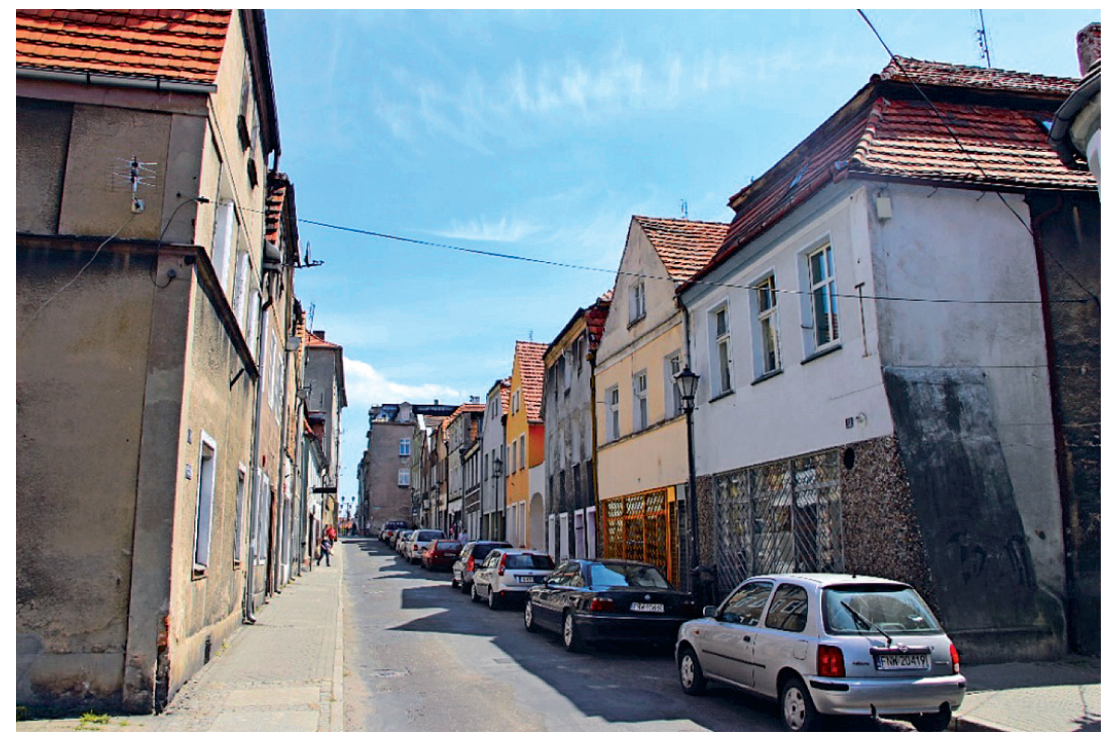

Fot. 7. Kożuchów, wjazd do starego miasta od strony zachodniej

Ruch kołowy w obrębie centrum miasta jest bardzo źle zorganizowany. Nieczytelny, zwłaszcza dla osób spoza Kożuchowa, jest dojazd do wnętrza starego miasta. Również nieczytelna jest organizacja ruchu w systemie ulic jednokierunkowych. Mała ilość parkingów, zarówno dla mieszkańców miasta jak i dla turystów, jest przyczyną powstawania tzw. „dzikich" parkingów. Ruch pieszy, jako istotny element komunikacji, również należy przeorganizować. Widoczny jest brak segregacji ruchu pieszego i kołowego. Nieczytelna jest organizacja ruchu pieszego. Nie ma wytyczonych i oznakowanych tras turystycznych.

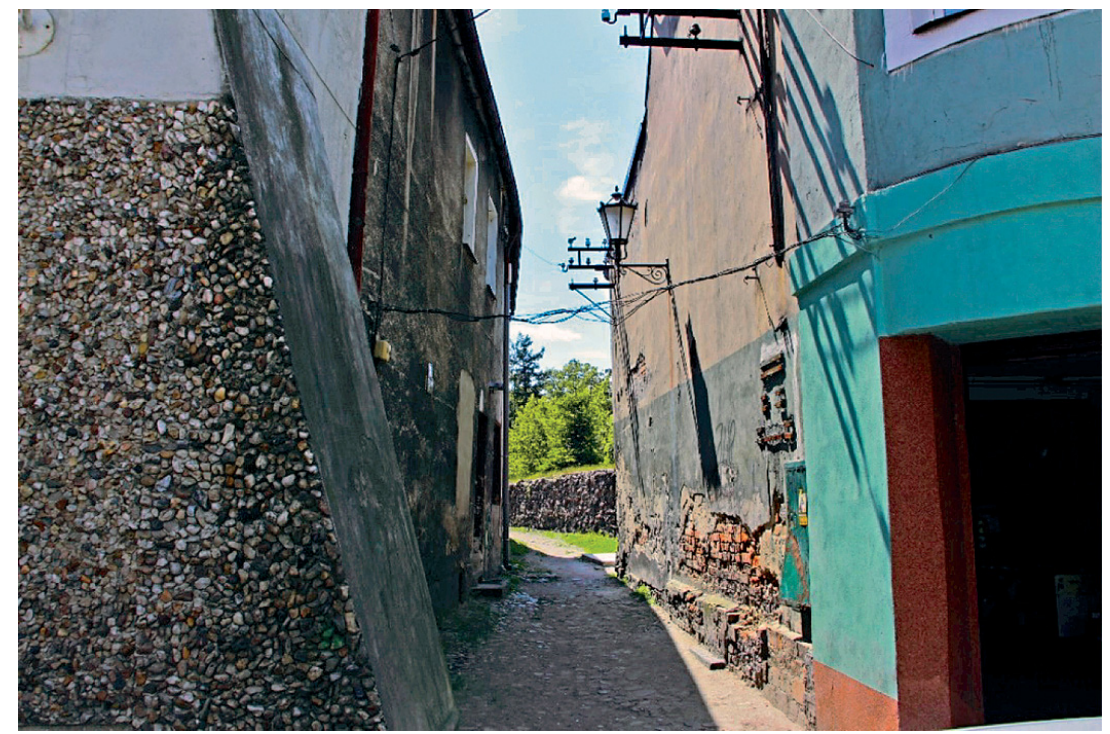

Fot. 8. Kożuchów, uliczka przymurna w zachodniej części starego miasta 
Komunikacja kołowa i piesza powinna odbywać się przez cztery „bramy” miejskie. Wewnątrz miasta może powstać tzw. „mała obwodnica” wzdłuż ulic tworzących wydłużony prostokąt na osi północ - południe. W związku z tym niezbędne będzie przeprojektowanie ulic w części południowej miasta oraz realizacja nowej drogi w części północnej.

Dla obsługi komunikacji kołowej planuje się, w bliskiej odległości centrum, budowę parkingów. Największy po wschodniej stronie, pomiędzy parkiem a murami obronnymi. Dwa mniejsze po stronie południowej i zachodniej.

Komunikacja piesza odbywać się może w zamkniętej dla ruchu kołowego strefie „małej obwodnicy”. Obszar ten powinien zostać całkowicie wyłączony z ruchu kołowego. Powstanie w ten sposób śródmiejski deptak, który w przyszłości będzie można rozbudowywać o nowe odcinki.

Ważnym elementem komunikacji miasta będą trasy turystyczne. Najważniejsza z nich prowadzić będzie wzdłuż murów obronnych miasta.

\section{Zieleń}

Kożuchów nie charakteryzuje się wysokimi walorami naturalnymi. Urzeźbienie terenu miasta, polegające na różnicach wyniesień, nie stwarza warunków dla ciekawych ekspozycji elementów krajobrazu naturalnego. Jedynie Stare Miasto otoczone murami obronnymi posiada takie walory. Głębokie fosy tworzą interesujące ramy dla wyniesionego wyżej średniowiecznego miasta.

Dlatego bardzo istotnym elementem w programie rewitalizacji Kożuchowa jest uporządkowanie istniejących i organizacja nowych terenów zielonych.

W centrum miasta istnieje niewielka ilość wartościowych egzemplarzy zieleni wysokiej i dość duże zdegradowane obszary zieleni niskiej. Ponadto, co stanowi ewenement w skali regionu, bardzo duże tereny zieleni niezorganizowanej, tzw. „dzikich” ogródków działkowych. Największa ich ilość znajduje się w północno-wschodniej oraz południowo-wschodniej części miasta, po wewnętrznej stronie murów obronnych a także od strony południowo-zachodniej, po zewnętrznej stronie murów. Są to potencjalne tereny dla miejskiej zieleni zorganizowanej w sposób planowy.

\section{Ogrody, parki}

Planowana jest likwidacja „dzikich” działek ogrodniczych. Odzyskany w ten sposób teren przekształcony zostanie w parki miejskie. Stare Miasto otoczone zostanie pierścieniem zieleni wysokiej (od wewnątrz) oraz zieleni niskiej (po zewnętrznej stronie murów obronnych). Powstanie w ten sposób rodzaj plant, zielonych terenów typowych dla miast organizujących zieleń na terenach pofortyfikacyjnych. Te nowe tereny zielone przestaną być miejscami niedostępnymi dla mieszkańców Kożuchowa. Staną się publiczną przestrzenią dostępną zarówno dla mieszkańców miasta jak i dla turystów. Wyeksponowane zostaną równocześnie na ich tle oraz w ich sąsiedztwie najatrakcyjniejsze zabytki Kożuchowa - mury obronne miasta.

Ogródki działkowe po stronie południowo-zachodniej oraz wschodniej (w fosie) zastąpione zostaną zielenią niską.

\section{Skwery, zieleńce}

Skwery i zieleńce zlokalizowane w miejscu dawnych zabudowanych kwartałów będą zlikwidowane. Miejsca te zostaną przeznaczone pod zabudowę zwartą. 


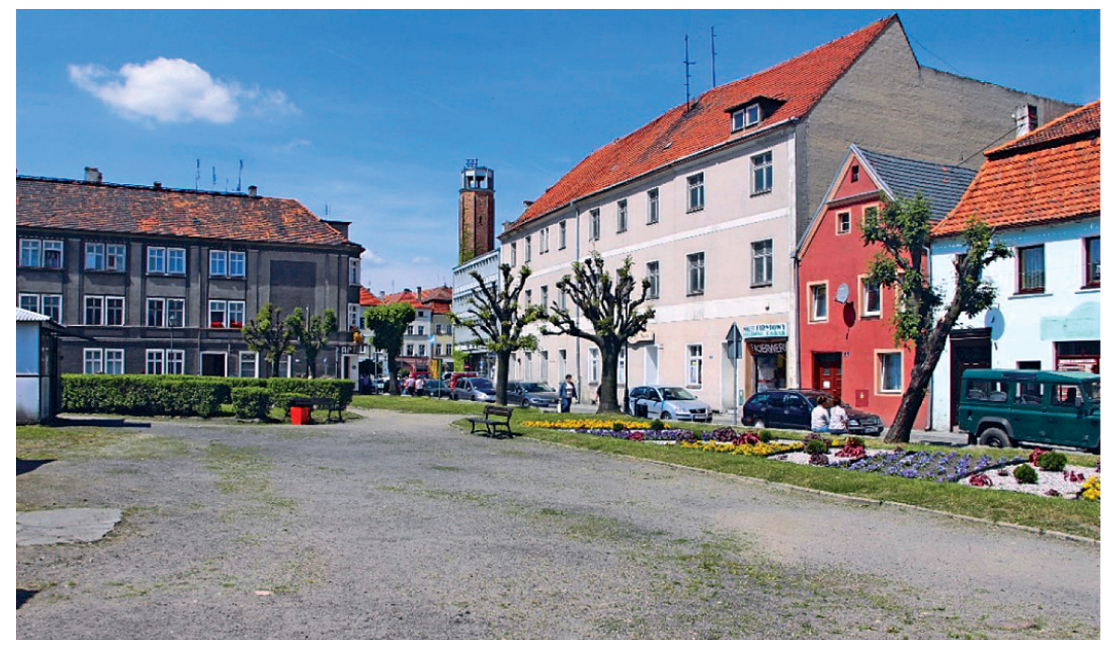

Fot. 9. Kożuchów, zaniedbany skwer, miejsce po dawnej zabudowie po stronie wschodniej od rynku

\section{Zieleń wnętrz mieszkalnych}

W zamian za „utracone” skwery planuje się nasycenie miasta zielenią zlokalizowaną w środku zamkniętych kwartałów zwartej zabudowy, zarówno istniejącej jak i projektowanej. Charakter tej zieleni będzie odpowiadał zarówno typowi zabudowy jak i przestrzeni ograniczonej tą zabudową.

\section{Ciągi piesze związane $z$ fortyfikacjami}

Wzdłuż murów miejskich projektuje się ciągi piesze. Przebiegać będą one po zewnętrznej stronie murów, wzdłuż fosy, częściowo od strony wschodniej a także południowej i zachodniej. Wewnętrzny ciąg pieszy przebiegać będzie wzdłuż całego obwodu obronnego oraz na północ od zamku.

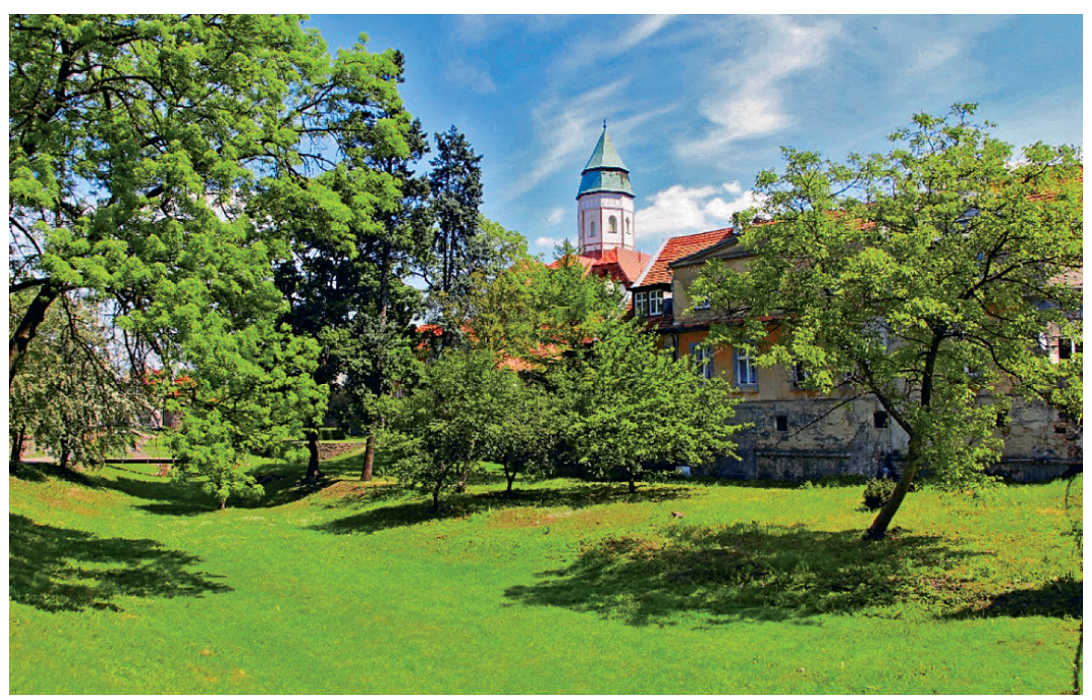

Fot. 10. Kożuchów, fragment fosy miejskiej, widok od południowego zachodu 


\section{Fortyfikacje}

Najcenniejszym zabytkiem Kożuchowa są relikty średniowiecznych fortyfikacji miasta. Zachowane w dobrym stanie prawie na całym obwodzie stanowią wyjątkowy w skali Polski przykład budownictwa obronnego. Kożuchów, podobnie jak wiele innych miast na Śląsku, pierwotnie otoczony był umocnieniami drewniano-ziemnymi. Jednak już na początku XIV wieku miasto otoczono wysokim kamiennym murem wzmocnionym gęsto rozmieszczonymi basztami. Przed murem znajdowała się szeroka wypełniona wodą fosa. W XV wieku fortyfikacje zostały zmodernizowane. Wzniesiono drugi, zewnętrzny pierścień kurtyn, niższy od wewnętrznego i zaopatrzony w masywne basteje. Wewnętrzny pas murów zwieńczony był gankiem bojowym z przedpiersiem zaopatrzonym w liczne otwory strzelnicze. Zewnętrzna kurtyna wraz z bastejami zwieńczona była krenelażem. Do miasta prowadziły cztery bramy. Od wschodu Brama Głogowska, od północnego-zachodu Brama Krośnieńska, od zachodu Brama Żagańska i od południa Brama Szprotawska. Fortyfikacje miasta sprzężone z znajdującym się w północnej części zamkiem i jego umocnieniami stanowiły przez stulecia skuteczny system obronny Kożuchowa.

Fortyfikacje Kożuchowa nie były dotychczas przedmiotem kompleksowych badań historycznych, archeologicznych i architektoniczno-konserwatorskich. Niemniej ten bezcenny zespół budowli obronnych już teraz warty jest zagospodarowania i udostępnienia dla turystów.

W planach rewitalizacji Starego Miasta przewiduje się wykorzystanie pozostałości systemu obronnego dla celów komercyjnych. Należy podkreślić jednak, że wszystkie prace przy murach obronnych powinny być poprzedzone specjalistycznymi badaniami naukowo-technicznymi.

\section{Zamek}

W ubiegłym roku przeprowadzono renowację zamku. Dotychczasowy tynk, tzw. cyklinę, zastąpiono tynkiem gładkim. Po przeprowadzeniu badań stratygraficznych zamek pomalowano kolorami nawiązującymi do oryginalnych.

Dojście do zamku zlokalizowane na nasypie gruntowym przecinającym fosę należy zastąpić drewnianym mostem zwodzonym nawiązującym charakterem do budowli militarnych.

Wzdłuż północnego odcinka murów obronnych, na stokach fosy, należy wykonać kamienne schody ułożone na gruncie. W tym miejscu rozpoczynać się będzie trasa turystyczna biegnąca wzdłuż murów obronnych.

\section{Fosa}

Fosę na całej jej długości należy przeznaczyć na trasę turystyczną. Niezbędne będzie jej oczyszczenie i odwodnienie. Należy również wykonać przejścia umożliwiające wejście lub wyjście $\mathrm{z}$ rowu w kierunku miasta.

\section{Muzeum sztuki militarnej}

W poprzemysłowym budynku usytuowanym we wschodniej części miasta, w bezpośrednim sąsiedztwie fosy, planuje się siedzibę muzeum sztuki militarnej. Należy przywrócić pierwotną formę budynku a wnętrze adaptować na nowe funkcje. 


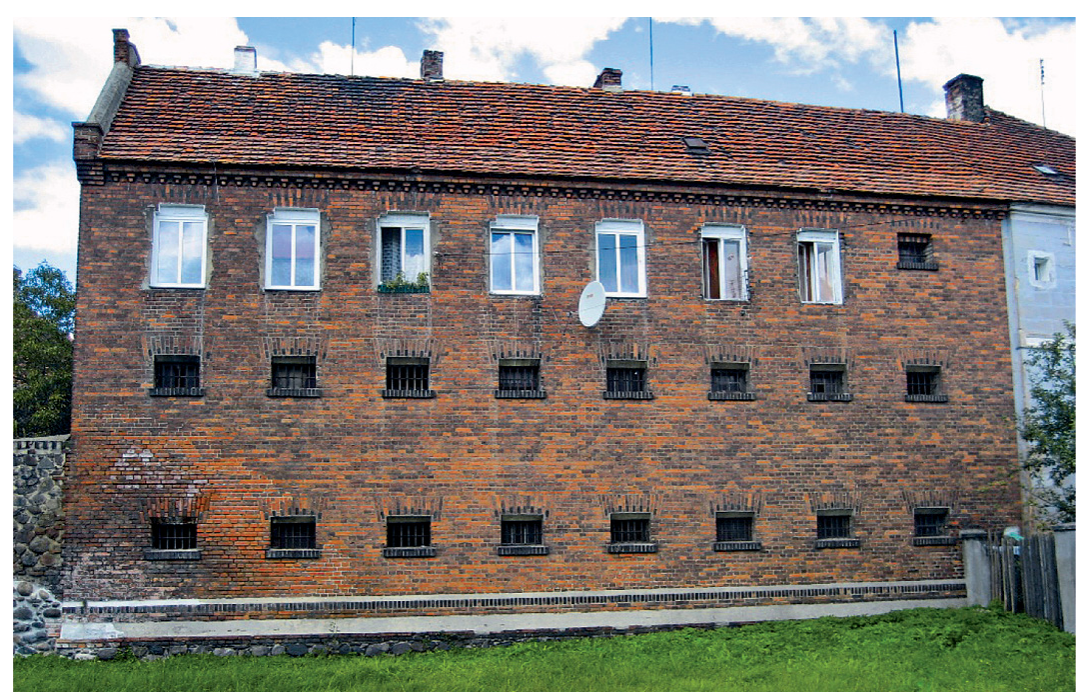

Fot. 11. Kożuchów, poprzemysłowy budynek wzniesiony w linii murów obronnych od strony południowej

\section{Most Bramy Szprotawskiej}

Wał ziemny przecinający fosę w osi dawnej bramy miejskiej należy zastąpić murowanym z kamienia arkadowym mostem. Pozwoli to na utrzymanie komunikacji w tym miejscu miasta a jednocześnie uczytelni fosę oraz pozwoli na bezkolizyjne przejście trasy turystycznej pod mostem.

Powyższe przedsięwzięcia mają spowodować, że system obronny Kożuchowa stanie się największą atrakcją turystyczną miasta a także regionu. Wydaje się, że w najbliższym czasie turystyka będzie jednym z najważniejszych czynników miastotwórczych.

\section{Modernizacja zabudowy kubaturowej}

Przedmiotem koncepcji rewitalizacji jest wyodrębniony zespół staromiejski średniowiecznego miasta warownego o wysokich walorach historycznych. Teren posiada wyraźnie zachowane granice w postaci obwarowań fortyfikacyjnych. Zachowane trzynastowieczne rozplanowanie ulic, zespół zabytkowych kamienic z okresu od XVI do początku XX wieku, monumentalna architektura kościoła, zamku i ratusza, pas murów obronnych, tworzą zespół urbanistyczny o wyjątkowej wartości zabytkowej.

Zespół staromiejski cechuje umiarkowana skala zabudowy i tradycyjne dominanty budowli fortyfikacyjnych i sakralnych. Specyficzny charakter Starego Miasta polega na harmonijnym układzie działek i ulic wypełnionych architekturą o tradycyjnej formie i skali obiektów trzykondygnacyjnych wokół rynku oraz dwukondygnacyjnych na pozostałych ulicach, sytuowanych szczytowo do rynku lub ulicy. Znaczna grupa kamienic jest posadowiona na gotyckich parcelach i utrzymana w dawnym gabarycie. W fasadach XVI - wiecznych kamienic rynkowych zachowały się nieliczne renesansowe rzeźbione kamienne portale. Odzwierciedlenie baroku zachowało się w fasadzie z płaskorzeźbionymi figurami Piotra i Pawła (ul. Klasztorna 6).

Większość budynków jest trzytraktowa, kamienice założone są na rzucie wydłużonego prostokąta. Na poziomie parteru przebiega przejście na podwórze. W drugim trakcie umieszczona jest klatka schodowa, w trakcie przednim lokal sklepowy lub usługowy, w tylnym 
duże pomieszczenie nazywane izbą tylną. Przekrycie stanowią sklepienia krzyżowe, kolebkowe lub strop drewniany.

Obiekty kubaturowe wymagają licznych zabiegów: remontów, restauracji elewacji, modernizacji, rozbudowy, nadbudowy.

Występują luki w kompozycji przestrzennej zespołu, zachodzi więc potrzeba zintegrowania istniejącej zabudowy w zwarty i kompletny zespół miejski przez uzupełnienia współczesną, odpowiednio dostosowaną do otoczenia architekturą. Postuluje się przywrócenie zespołowi formy możliwie zbliżonej do pierwotnej, dążenie do zachowania zabytkowego charakteru całości.

W sylwecie staromiejskiej istnieje rozrzut punktów wysokościowych, niekorzystnie konkurujących ze starymi. W XX wieku w zespole staromiejskim powstały trzy czterokondygnacyjne bloki mieszkalne (ul. Rynek, ul. Klasztorna, ul. Mickiewicza) zakłócające dawny układ przestrzenny, przytłaczające optycznie pobliski zamek. Spowodowały zakłócenie panoramy historycznego miasta. Budynki te usytuowane w pobliżu zamku, murów obronnych, popsuły całkowicie osie widokowe. Zachwiana została także zabytkowa skala. Zgodnie z powszechnie stosowana zasadą, w zespołach staromiejskich najwyższe i najbardziej okazałe budynki stały na centralnie położonym rynku, a wysokość obiektów malała proporcjonalnie do oddalania się od środka miasteczka. Budynki czterokondygnacyjne zbudowane zostały obok trzy- i dwukondygnacyjnych.

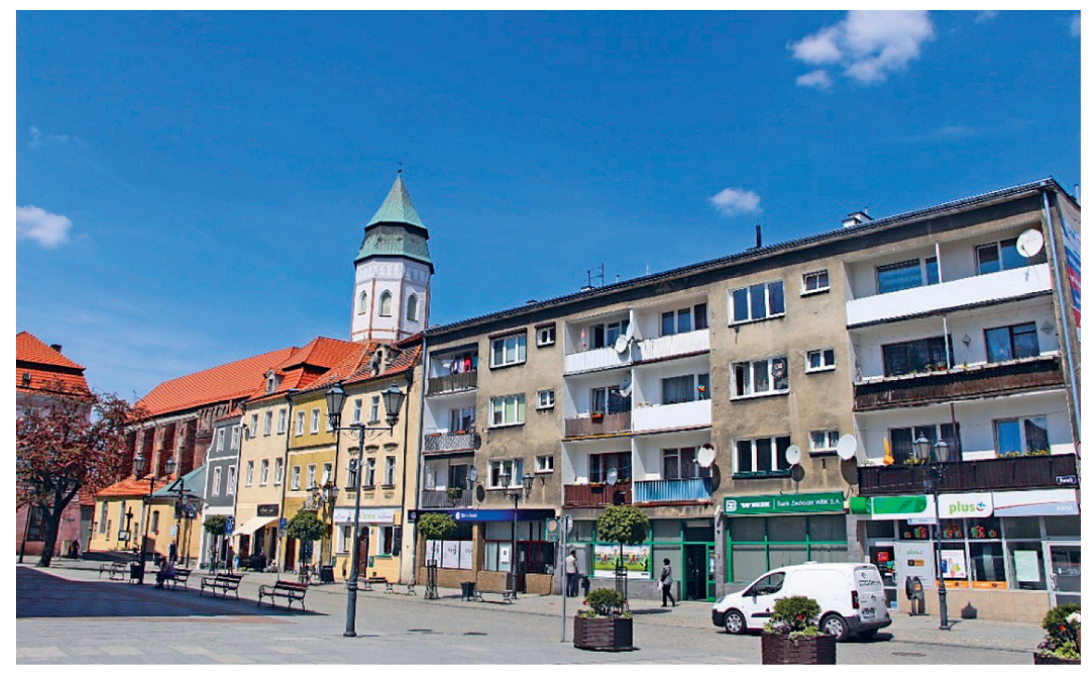

Fot. 12. Kożuchów, zabudowa w północnej pierzei starego rynku

Zaleca się odtworzenie historycznego krajobrazu miejskiego przez poprawę kompozycji i form zabudowy wynikające z przesłanek historyczno-estetycznych. Zmiany i korekty dotyczą fragmentów dysharmonizujących, zakłócających lub szpecących zespół.

\section{Działania konserwatorskie}

W celu prawidłowego ukierunkowania niezbędnych przekształceń i modernizacji postuluje się przeprowadzenie następujących działań konserwatorskich:

Rozbiórki - usunięcie elementów nie stanowiących części składowych zespołu staromiejskiego w sensie historycznym i kompozycyjnym. 


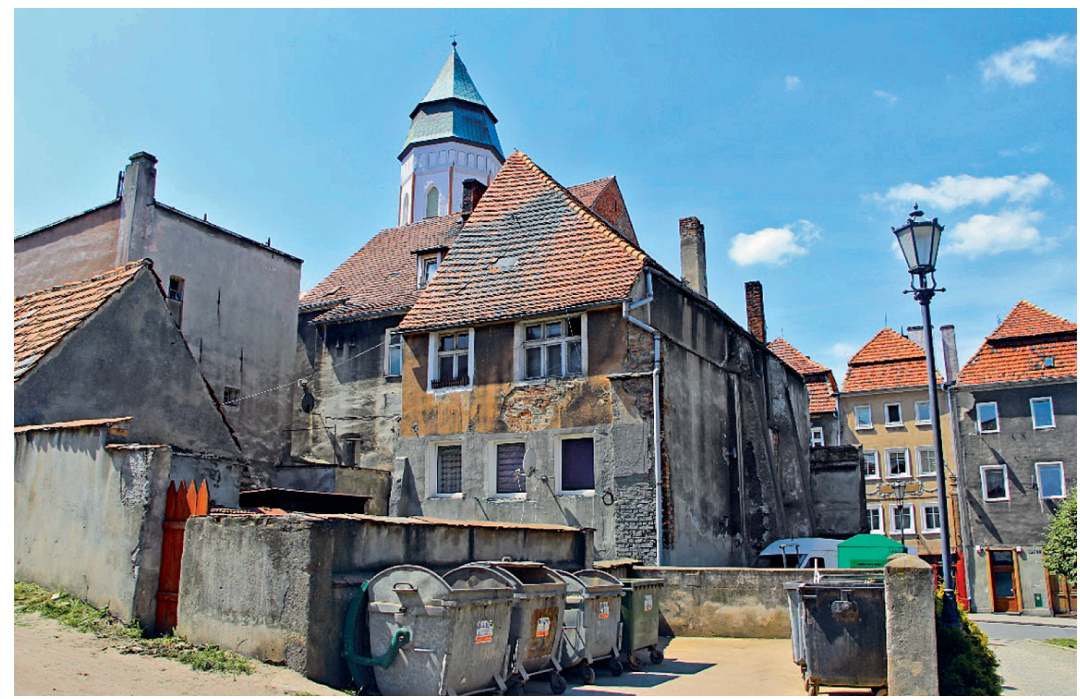

Fot. 13. Kożuchów, zabudowa na tyłach kamienic w północnej części starego rynku

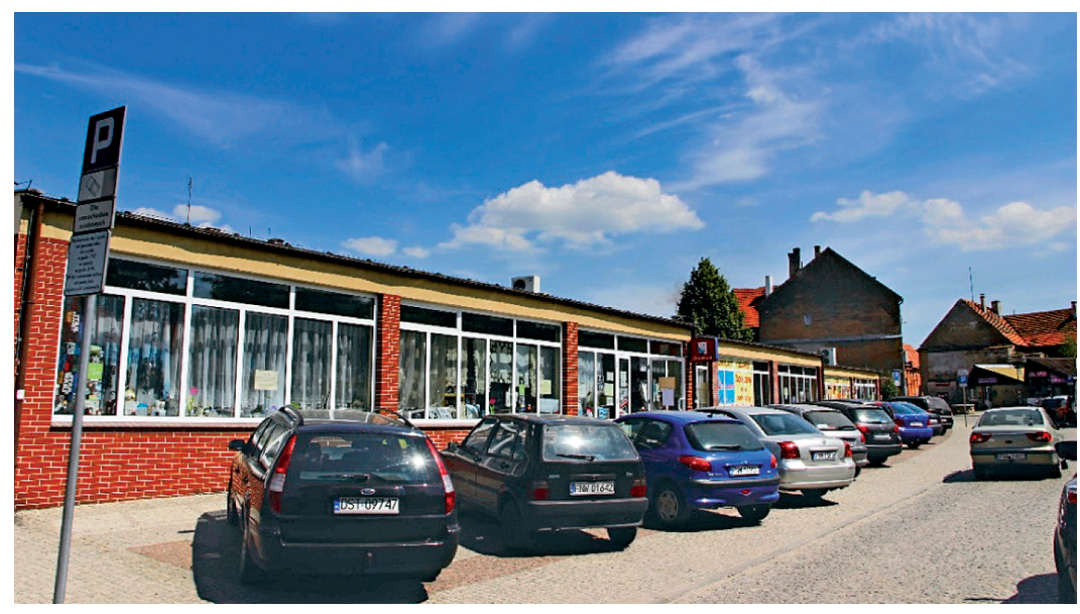

Fot. 14. Pawilony handlowe we wschodniej części starego miasta

Postuluje się zaplanowanie ogólnego uporządkowania terenu polegające na usunięciu obiektów tymczasowych, zabudowy oficynowej, garaży, budynków gospodarczych (ul. Mickiewicza, Kościelna, Legnicka, Głogowska, Limanowskiego, Obywatelska, Daszyńskiego) z pozostawieniem jednak fragmentów zabudowy oficynowej przeznaczonej do modernizacji (ul. Krzywoustego).

W celu odtworzenia modelu przestrzennego Starego Miasta proponuje się rozbiórkę budynków dysharmonizujących ze średniowiecznym układem ulic przy ul. Legnickiej 19, Mickiewicza 12, Głogowskiej 3, Głogowskiej 2.

Modernizacja - przywrócenie zespołowi właściwych walorów kompozycyjnych polegających na korekcie stanu zabudowy oraz uporządkowaniu gabarytów przez przebudowę niektórych obiektów. 
Modernizacja elewacji budynków (ul. Rynek) powinna polegać na odsłonięciu wcześniejszych warstw i form stylowych elewacji z odtworzeniem detalu architektonicznego i jednocześnie wnosząca elementy współczesne wpisujące się harmonijnie w historyczną strukturę Starego Miasta.

Zakres ingerencji budowlanej podczas modernizacji obiektów znajdujących się w rejestrze zabytków powinien być ograniczony, nie może spowodować zniszczeń detalu architektonicznego, układów wnętrz, sklepień, klatek schodowych itp.

Postuluje się rozbudowę budynków z korektą linii zabudowy według średniowiecznego układu urbanistycznego. Zaleca się modernizację budynków czterokondygnacyjnych z rozbudową korygującą linię zabudowy ul. Klasztornej. Należy także wykonać rozbudowę pawilonów handlowych przy ul. Daszyńskiego w celu odtworzenia średniowiecznej linii zabudowy ulicy.

Reintegracja - uzupełnienie zabudowy w celu odzyskania historycznego układu urbanistycznego.

Postuluje się odtworzenie zabytkowej struktury przestrzennej przez wprowadzenie nowej zwartej zabudowy o odpowiedniej skali, gabarytach, stromych dachach, usytuowanej na historycznych liniach zabudowy.

Należy odzyskać wszystkie walory układu przestrzennego. W celu podkreślenia średniowiecznego charakteru miasta zaleca się stosować w projektowanych obiektach zabudowę szczytową. Projektowane uzupełnienia zabudowy powinny nawiązywać do dawnego charakteru i jednocześnie powinny zapobiegać fałszowaniu historii. Zaleca się, aby uzupełnienia historycznej struktury urbanistycznej polegały na poszukiwaniu współczesnej formy architektonicznej zharmonizowanej z zabytkowym otoczeniem staromiejskim. Nowo wznoszone obiekty nie powinny przekraczać tradycyjnych wysokości i gabarytów brył zabudowy. Powinny być w tej samej konwencji przestrzennej, w jakiej ukształtował się niegdyś zespół staromiejski.

Postuluje się odtworzenie pierzei przy ul. Mickiewicza, Legnickiej, Głogowskiej, Daszyńskiego oraz uzupełnienie zabudowy pojedynczymi „,plombami” przy ul. Klasztornej, Kościelnej.

\section{Zakończenie}

Zachowane prawie na całym obwodzie fortyfikacje uniemożliwiły scalenie się centrum z przedmieściami. Dzięki temu zachowało się pierwotne rozplanowanie tej części miasta i jego historyczny charakter.

Te walory są jednak dużym wyzwaniem dla urbanistów i architektów w pracach planistyczno-urbanistycznych. Samo stare miasto stało się miejscem węzłowym w układzie przestrzennym Kożuchowa. Ponadto, w nim samym, jest wiele dodatkowych węzłowych miejsc. Są to budowle mające znaczące wartości kulturowe: zamek, ratusz, gotycki kościół, zabudowa mieszkalna. Jest to również system fortyfikacyjny z dobrze zachowanymi kurtynami, basztami, bastejami i fosą. Historyczny układ ulic nie ułatwia komunikacji pieszej i samochodowej na Starówce. Tereny zielone kryją ogromny potencjał. Niestety jest też dużo elementów degradujących miasto: budynki gospodarcze, zaniedbane podwórka, współczesna zabudowa tzw. bloki, pawilony handlowe, niezabudowane działki i kwartały.

W opracowaniu przedstawiono próbę analizy problemów oraz propozycje zmian mogących doprowadzić do uporządkowania miejskiej struktury przestrzennej Kożuchowa, tak aby zachowany został wyjątkowy charakter tego miasta a jednocześnie powstała wartość dodana wynikająca z wprowadzenia nowych propozycji architektonicznych i urbanistycznych. 


\title{
Literatura
}

[1] Kowalski S., Muszyński J. Kożuchów. Zarys historii. Kożuchów 1995.

[2] Kowalski S. Zabytki architektury województwa lubuskiego, Zielona Góra 2010.

[3] Kożuchów. Zarys dziejów. Andrzejewski T. (red.), Kożuchów 2003.

[4] Szukiełowicz Z., Andrzejewski T. Mury obronne Kożuchowa w świetle nowych ustaleń, w: Budownictwo obronne Środkowego Nadodrza. Nowa Sól 2003.

[5] Andrzejewski T., Miejscowości powiatu nowosolskiego. Rys historyczny. Nowa Sól 2004.

\section{Kożuchów - a historical town with a future}

\author{
Wojciech Eckert
}

\begin{abstract}
Institute of Civil Engineering, Faculty of Civil Engineering, Architecture and Environmental Engineering, University of Zielona Góra, e-mail: w.eckert@ib.uz.zgora.pl
\end{abstract}

\begin{abstract}
Kożuchów is a unique town, not only in the Lubusz Voivodship but also in the whole country. The well-preserved defence system, consisting of two rings of curtains and a moat, distinguishes this town from hundreds of others. It is also one of the oldest towns in the Middle Oder Region. Nearly the entire circumference of the fortifications has been prevented, which makes it impossible to merge the centre with the suburbs. For this reason, the original layout of this part of the town and its historical character have been preserved. However, these factors are a big challenge for urbanists and architects in terms of urban-planning. The old town has become a central point in the spatial layout of Kożuchów. Moreover, there are a number of additional important objects such as buildings of significant cultural value: the castle, the town hall, the gothic church and the residential buildings as well as the fortification system with the well-preserved curtains, bastion, fortified towers and moat. The historical layout of the streets makes walking and driving difficult in the Old Town. The green areas have enormous potential. Unfortunately, there are also a number of elements spoiling the look of the town: the business buildings, the neglected yard, the modern buildings - so called blocks of flats, the commercial pavilions, the undeveloped plots and quarters. The paper presents an attempt to analyse the problems and to provide suggestions for changes so as to preserve the unique character of the town and, at the same time, to add value resulting from the introduction of new architectural and urban-planning ideas.
\end{abstract}

Keywords: urbanism, architecture, spatial layout, old town, defence system, revitalisation. 